\title{
Association between KLOTHO Gene G395A Polymorphism and Carotid Artery Calcification in regular Hemodialysis Patients
}

\author{
Herwindo Ahmad $^{1 *}$, Riri Andri Muzasti ${ }^{2}$, Syafrizal Nasution ${ }^{2}$ \\ ${ }^{1}$ Department of Internal Medicine, Faculty of Medicine, Universitas Sumatera Utara, Adam Malik General Hospital, Medan, \\ Indonesia; ' ${ }^{2}$ ivision of Nephrology-Hypertension, Department of Internal Medicine, Faculty of Medicine, Universitas Sumatera \\ Utara, Adam Malik General Hospital, Medan, Indonesia
}

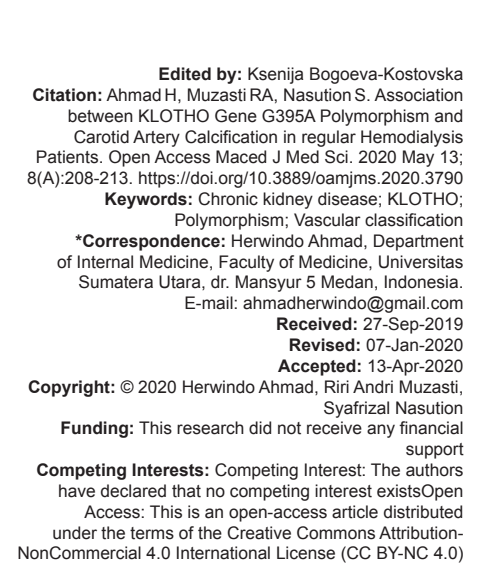

\section{Introduction}

The incidence of chronic kidney disease (CKD) in the world remains high and becomes a major global health burden. CKD can develop into end-stage renal disease (ESRD) which requires renal replacement therapy such as hemodialysis [1]. In Norway, the incidence of CKD is $10,2 \%$ of total population. This result is similar in China where the incidence is 7,2$13,7 \%$ [2]. There are so many complications of CKD, one of them is a mineral abnormality in the form of vascular classification [3]. This situation is an important contributor to the incidence of cardiovascular disease that determines the mortality of patients with CKD [4].

In our body, there are some promoter and inhibitor of vascular classification to maintain the calcification process in vascular. KLOTHO, a transmembrane protein expressed in kidney, is one of the classified inhibitors [5]. KLOTHO gene has been reported to be related to bone density, coronary artery disease, and cardiovascular risk factors such as the homeostasis calcium and phosphate in the kidney.
The defect in this gene shows the acceleration of vascular atherosclerosis along with classification [6]. All experiments to date have shown the protective effect of KLOTHO on the incidence of vascular classification [5]. Single-nucleotide polymorphisms (SNPs) are inherited human gene variations when a single nucleotide changes in the genome sequence [7]. In the KLOTHO gene, SNPs on G395A are very common in Asian populations [8]. So far, there are no data on whether the G395A KLOTHO gene polymorphism is related to carotid artery calcification in regular hemodialysis patients in Indonesia, so the authors are interested in conducting this study.

\section{Methods}

\section{Study design}

This study was an analytical research method with cross-sectional design in June-August 2018 
at Rasyida Kidney Hospital, Medan. The Faculty of Medicine, Universitas Sumatera Utara Ethics Committee approved this study. The main objective of this research was to determine whether there was an association between KLOTHO gene G395A polymorphism and carotid artery classification in regular hemodialysis patients.

\section{Selection of participants}

Subjects over the age of 18, CKD patients who have undergone regular hemodialysis (HD) $\geq 3$ months, cooperative patients, and willing to participate by signed an informed consent form were served as research inclusion criteria. We determined the comorbid diseases, duration of hemodialysis from history taking and medical record, and calculated the body mass index (BMI). Then, the research subjects were taken a blood sample to evaluate the calcium and phosphate serum levels, the KLOTHO gene G395A polymorphisms and carotid ultrasonography were done to evaluate the carotid intima-media thickness (CIMT)

The KLOTHO gene G395A polymorphism was examined by polymerase chain reaction with confronting two-pair primers method (PCR-CTTP). In this genotyping of G395A in the promoter region procedure, as described previously by Shimoyama et al. (2009), the confronting pairs of primers are as follows: Forward primer 1: GTTTCGTGGACGCTCAGGTTCATTCTC, forward primer2:GAGAAAAGGCGCCGACCAACTTTC, reverse primer 1: GATCCCGCCCC- CAAGTCGGGA, and reverse primer 2: GTCCCTCTAGGATTTCGGCCAG [9]. These polymorphism regions were amplified by $\mathrm{PCR}$ for 10 min with the initial denature at $95^{\circ} \mathrm{C}$ followed for $1 \mathrm{~min}$ at $95^{\circ} \mathrm{C}$ (35 cycles), for $1 \mathrm{~min}$ at $65^{\circ} \mathrm{C}$, for $1 \mathrm{~min}$ at $72^{\circ} \mathrm{C}$, and additionally for $5 \mathrm{~min}$ at $72^{\circ} \mathrm{C}$ and the products were visualized with $3 \%$ agarose gel and ethidium bromide staining. The GG genotype is located at $252 \mathrm{bp}$ (base pair) and $175 \mathrm{bp}$, the GA genotype at 252, 175, and $121 \mathrm{bp}$, and the AA genotype at 252 and 121 bp (Figure 1). Research subjects were also done the carotid ultrasonography examination to evaluate the carotid intima-media thickness (CIMT). CIMT is defined as the measurable distance between the intima lumen and the media-adventitia boundary [10]. A positive result is if the CIMT $>1 \mathrm{~mm}$.

\section{Statistical analysis}

We performed the univariate, bivariate, and multivariate analysis. The distribution of subject characteristics was analyzed by univariate analysis and displayed as a percentage. The association between independent and dependent variables was analyzed by bivariate analysis. For categorical variables, we performed Chi-squared test or Fisher's exact test as an alternative while numerical variables were analyzed by independent t-test or Mann-Whitney U-test as an

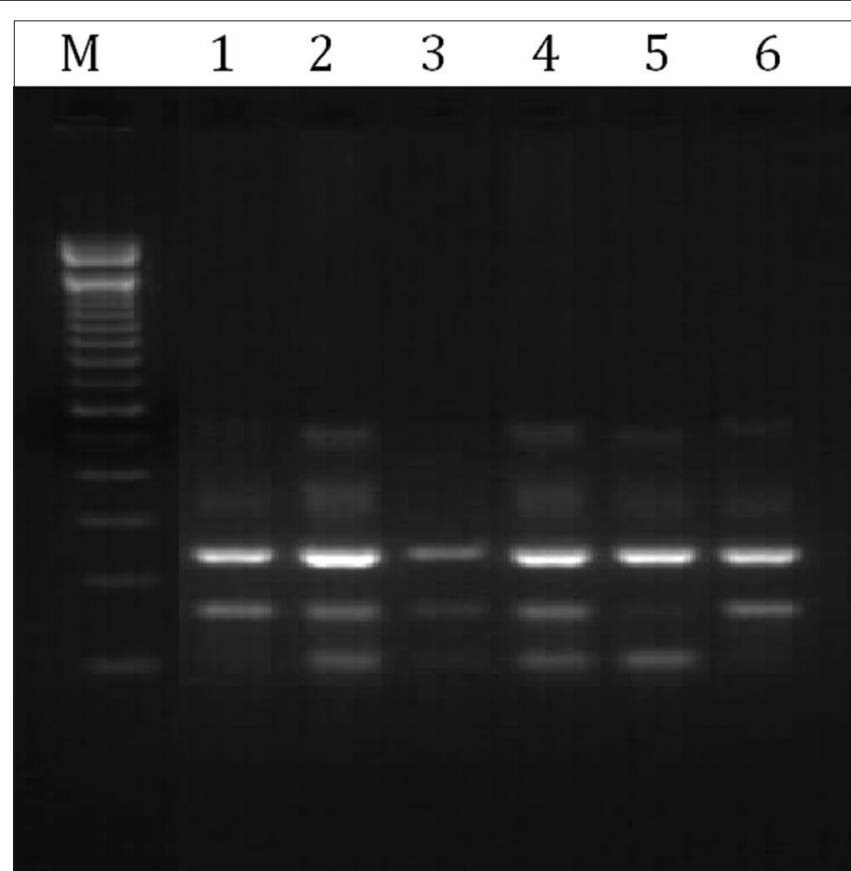

Figure 1: The PCR-CTTP analysis for genotype of KLOTHO gene G395A polymorphisms. Lanes 1, 3, and 6 indicate the GG genotype, lanes 2 and 4 indicate GA genotype, lane 5 indicates the AA genotype

alternative. Multivariate analysis was performed by regression logistic test. The significant results was considered if $p<0,05(p<0,05)$.

\section{Results}

\section{Characteristics of research subjects}

From a total of 69 research subjects, the majority of subjects were men as many as $35(50,7 \%)$ subjects with median age was 55 (26-78) years old. Hypertension was the most comorbid disease as many as $53(76,8 \%)$ subjects followed by diabetes mellitus as many as $16(23,3 \%)$ subjects. The normal BMI group was the most in this study as many as $26(18,8 \%)$ subjects (Table 1).

From the KLOTHO gene G395A polymorphisms examination, we found that the majority of subjects had GG genotype as many as $36(52,2 \%)$ subjects followed by GA genotype as many as $30(43,5 \%)$ subjects and AA genotype as many as $3(4,3 \%)$ subjects. Based on carotid ultrasonography examination, it was found that the majority of subjects had CIMT $\leq 1 \mathrm{~mm}$, as many as $41(59,4 \%)$ subjects (Table 1$)$.

\section{Association between research subjects characteristics and KLOTHO gene -395 polymorphisms with carotid artery calcification}

We performed a bivariate analysis to determine the association of research subjects characteristics 
Table 1: Baseline characteristics

\begin{tabular}{ll}
\hline Characteristics & Frequency $(\mathrm{n}=69)$ \\
\hline Sex, $\mathrm{n}(\%)$ & $35(50.7 \%)$ \\
Men & $34(49.3 \%)$ \\
Women & $55(26-78)$ \\
Age, median (min-max), years old & \\
Comorbid disease, $\mathrm{n}(\%)$ & $53(76.8 \%)$ \\
$\quad$ Hypertension & $16(23.2 \%)$ \\
Diabetes mellitus & $60(33-135)$ \\
Duration of HD, median (min-max), months & $23.6(16.7-42.6)$ \\
BMI, median (min-max), kg/m ${ }^{2}$ & \\
BMI categories, $\mathrm{n}(\%)$ & $2(1.4 \%)$ \\
Type 2 obesity & $5(3.6 \%)$ \\
Type 1 obesity & $18(13 \%)$ \\
Pre-obesity & $14(10.1 \%)$ \\
Overweight & $26(18.8 \%)$ \\
Normal & $4(2.9 \%)$ \\
Underweight & $9.8(8.0-10.9)$ \\
Calcium levels (Ca), median (min-max), mg/dL & $5.5(0.63)$ \\
Phosphate levels (P), mean $( \pm$ SD), mg/dL & \\
KLOTHO gene -395 polymorphisms, $\mathrm{n}(\%)$ & $3(4.3 \%)$ \\
AA genotype & $30(43.5 \%)$ \\
GA genotype & $36(52.2 \%)$ \\
GG genotype & \\
Carotid ultrasonography interpretation, $\mathrm{n}(\%)$ & $28(40.6 \%)$ \\
Calcification & $41(59.4 \%)$ \\
No calcification &
\end{tabular}

to the incidence of carotid artery calcification. Based on statistical test, hypertension as comorbid disease $(p=0,009)$ and the categories of BMI $(p=0,039)$ are associated with the incidence of carotid artery calcification. Both of these risk factors along with other risk factors that have $p<0,25$, such as diabetes as comorbid disease and calcium levels, will be included in the multivariate analysis (Table 2).

Table 2. Association between research subjects characteristics with carotid artery calcification

\begin{tabular}{|c|c|c|c|}
\hline Risk factors & Calcification & No calcification & $p$ value \\
\hline Sex, n (\%) & & & $0.378^{\star}$ \\
\hline Men & $16(57.1)$ & $19(46.3)$ & \\
\hline Women & $12(42.9)$ & $22(53.7)$ & \\
\hline Diabetes, n (\%) & & & $0.145^{*}$ \\
\hline Yes & $9(32.1)$ & $7(17.1)$ & \\
\hline No & $19(67.9)$ & $34(82.9)$ & \\
\hline Hypertension, n (\%) & & & $0.009^{*}$ \\
\hline Yes & $26(92.9)$ & $27(65.9)$ & \\
\hline No & $2(7.1)$ & $14(34.1)$ & \\
\hline BMI categories, n (\%) & & & $0.039^{*}$ \\
\hline Overweight - obesity & $20(71.4)$ & $19(46.3)$ & \\
\hline Underweight - normal & $8(28.6)$ & $22(53.7)$ & \\
\hline Mean calcium levels, $\mathrm{mg} / \mathrm{dL}$ & 39.5 & 31.8 & $0.119^{8}$ \\
\hline Mean phosphate levels, mg/dL & 5.5 & 5.4 & $0.862^{\wedge}$ \\
\hline Median of age, year (min-max) & $54.5(26.0-69.0)$ & $57.0(31.0-78.0)$ & $0.437^{\&}$ \\
\hline $\begin{array}{l}\text { Median duration of HD, month } \\
\text { (min-max) }\end{array}$ & $53.5(33.0-131.0)$ & $63.0(35.0-135.0)$ & $0.353^{\&}$ \\
\hline
\end{tabular}

A bivariate analysis was performed to determine the association between the KLOTHO gene -395 polymorphisms on the incidence of carotid artery calcification. Based on statistical tests, a statistically significant association was found between the KLOTHO -395 gene polymorphisms and the incidence of carotid artery calcification with $p=0,015$. Furthermore, groups with $G A$ and $A A$ genotypes were known to increase risk factors by 4,071 times for carotid artery calcification compared to the GG genotype group ( $p=0,006$; $\mathrm{Cl} 95 \%=1,464-11.320)$. The presence of $\mathrm{A}$ alleles in a person is also known to increase the risk of carotid artery calcification by 2,292 times compared to individuals with $\mathrm{G}$ alleles ( $p=0,033 ; \mathrm{Cl} 95 \%=1,058$ 4,963) (Table 3).
We determined risk factors that influence the incidence of carotid artery calcification by multivariate analysis with logistic regression tests. The variables with $p \leq 0,25$ in the bivariate tests such as KLOTHO gene -395 polymorphisms GA and AA genotypes, history of diabetes, history of hypertension, calcium levels, and BMI categories will be included in the test.

Based on this analysis, risk factors that influence the incidence of carotid artery calcification were KLOTHO gene -395 polymorphisms GA and AA genotype, history of diabetes, and history of hypertension ( $p=0,002 ; p=0,022 ;$ and $p=0,006$ ) (Table 4). These three risk factors will increase the likelihood of carotid artery calcification. Based on these statistical tests, a formulation can be made in predicting the occurrence of carotid artery calcification as follows:

Possible calcification events $=(-2,479)+$ (1,996 GA and AA KLOTHO gene polymorphisms) $+(1,829$ history of diabetes $)+(2,336$ history of hypertension)

\section{Discussion}

CKD is an increasing public health problem where the prevalence of CKD in various regional countries varies with gender. Epidemiological studies conducted by Lebov et al. in the Pacific coastal regions of Nicaragua and El Salvador, in 2015, showed an increased in the incidence of CKD among young adult men and the average age of CKD occurrence is 51 $( \pm 12)$ years [11]. Our study showed the similar results, from 69 research subjects, the majority of subjects were men, as many as 35 people $(50.7 \%)$ with a median age of 55 years. Different results are shown as in the study of Carrero et al., in 2018, on gender differences in the epidemiology of CKD in some countries that the prevalence of CKD in the regional majority is more common in female as in Finland with a ratio of women to men which is 3,1:1,9 [12]. Testosterone has a bad effect on the kidneys because it induces apoptosis of podocyte cells which can develop into glomerulosclerosis and increases TGF- $\beta 1$ expression associated with the incidence of tissue fibrosis, while estradiol inhibits this process. Meanwhile, decreased estrogen levels have been linked to decrease nitric oxide (NO) synthesis in the renal medulla which is generally associated with kidney injury [13], [14], [15].

Various etiologies that cause kidney damage include primary glomerulopathy, hypertension, diabetes, and the presence of post-renal obstruction and others. Data from the Indonesian Renal Registry in 2017 show that hypertension is still the most common comorbid disease in CKD patients undergoing HD in Indonesia as many as $36 \%$ and followed by diabetes as much as $29 \%$ [16]. Our findings are consistent with the previous 
Table 3: Association between KLOTHO gene -395 polymorphisms with carotid artery calcification

\begin{tabular}{|c|c|c|c|c|c|}
\hline $\begin{array}{l}\text { KLOTHO gene -395 } \\
\text { polymorphisms }\end{array}$ & Calcification & No calcification & $p$ value $^{*}$ & PR & $\mathrm{Cl} 95 \%$ \\
\hline AA & $1(3.6)$ & $2(4.9)$ & 0.015 & - & - \\
\hline GA & $18(64.3)$ & $12(29.3)$ & & & \\
\hline GG & $9(32.1)$ & $27(65.3)$ & & & \\
\hline $\mathrm{GA}+\mathrm{AA}$ & $19(67.9)$ & 14 (34.1) & 0.006 & 4.071 & $1.464-11.320$ \\
\hline GG & 9 (32.1) & 27 (65.9) & & & \\
\hline$A$ allele & $20(35.7)$ & 16 (19.5) & 0.033 & 2.292 & $1.058-4.963$ \\
\hline $\mathrm{G}$ allele & 36 (64.3) & 66 (80.5) & & & \\
\hline
\end{tabular}

studies where the majority of subjects had comorbid hypertension in 53 people $(76.8 \%)$ and followed by diabetes mellitus in 16 people (23.3\%). Zhang et al., in 2012, conducted a study on the prevalence of CKD in China, out of 1185 subjects with a decrease in GFR $<60 \mathrm{ml} / \mathrm{min} / 1.73 \mathrm{~m}^{2}$, as many as $60.5 \%$ of the subjects had comorbid hypertension and $19.1 \%$ of the subjects had comorbid diabetes [17]. Hypertensive nephropathy in patients with pathological renal changes is indicated by the presence of vascular changes, glomerular ischemia, and acute tubular interstitial injury. Increased intraglomerular pressure caused by hypertension will lead to glomerulosclerosis [18].

Table 4: Risk factors that associated with carotid artery calcification (final stage of multivariate analysis)

\begin{tabular}{llllll}
\hline Risk factors & $\mathrm{B}$ & Wald & $\mathrm{P}^{*}$ & $\mathrm{PR}$ & $\mathrm{Cl} 95 \%$ \\
\hline $\begin{array}{l}\text { KLOTHO gene -395 } \\
\text { polymorphisms GA and AA } \\
\text { genotype }\end{array}$ & 1.996 & 9.796 & 0.002 & 7.363 & $2.109-25.704$ \\
$\begin{array}{l}\text { Diabetes } \\
\begin{array}{l}\text { Hypertension } \\
\text { Constanta }\end{array}\end{array}$ & & & & & \\
\hline *Logistic regression test & 1.829 & 5.264 & 0.022 & 6.230 & $1.306-29.731$ \\
& -2.479 & 7.620 & 0.006 & 10.343 & $1.969-54.337$ \\
& & & & & \\
\hline
\end{tabular}

Genetic and environmental factors are two factors that make variations in human phenotypes. When the DNA genome sequence on the same chromosomes of two individuals is compared, there is substantial variation in the order at many points throughout the genome. Single-nucleotide polymorphisms (SNPs) are a genetic variation that occurs when a singlenucleotide base changes in genome sequence and is inherited, which is the most common form of genetic variation. This genetic variation is believed to influence the tendency of people to suffer from certain diseases [7], [19], [20]. KLOTHO, a gene related to the aging process, has been known to have a role in atherosclerosis and cardiovascular disease. KLOTHO mRNA is mainly expressed in the kidneys (especially in the distal tubule) and it has been shown that serum KLOTHO levels begin to decrease in mild CKD patients (stage $\leq 2$ ) and this decrease occurs before the onset of increased serum fibroblast growth factor-23 (FGF23), parathyroid hormone (PTH), and phosphate [21], [22]. KLOTHO expression in humans can vary with singlenucleotide polymorphisms (SNPs). Several studies have identified polymorphisms in KLOTHO and are associated with various phenotypes. Recent research has focused on G-395A polymorphisms in the KLOTHO promoter area [6], [20].

From the results of the KLOTHO gene -395 polymorphism, we found that the majority of research subjects had GG genotype as many as 36 people
(52.2\%) followed by GA genotype as many as 30 people $(43.5 \%)$ and AA genotype as many as 3 people $(4,3 \%)$. This finding was consistent with a study of 478 HD patients in Korea which conducted by Ko et al., in 2013. They found that the majority of research subjects had KLOTHO gene -395 polymorphisms with GG genotype as many as 302 people $(63.2 \%)$ followed by GA genotype as many as 158 people (33\%) and AA genotype as many as 18 people (3.8\%) [6]. Nazarian et al., in Iran, with $60 \mathrm{HD}$ patients and 60 patients control group found that the majority of HD patients had KLOTHO gene -395 polymorphism of GG genotype as many as 42 people (70\%) [8].

Existing studies show the important role of KLOTHO in vascular calcification. The G395A polymorphism in the KLOTHO gene promoter region modifies bone mineral density, which appears to be related to atherosclerosis and arterial calcification, both of which have the potential to influence coronary heart disease [20]. Endothelial dysfunction is a systemic pathological condition caused by an imbalance between vasorelaxation and vasoconstriction of blood vessels. Nitric oxide is a vasodilator that is oxidized by acetylcholine and is a major endogenous vasodilator. Several studies have shown that KLOTHO can induce NO production, the expression of mitochondria superoxide dismutase (MnSOD), and suppression of NADPH oxidase to protect from oxidative stress or show an anti-inflammatory action in protecting endothelium [19], [23], [24], [25]. In animal subjects, namely, mutant rats or mice performed by nephrectomy, it can be seen the acceleration of the development of atherosclerosis due to the effects of this gene in production of NO [26]. Furthermore, KLOTHO deficiency in mice produces increase phosphate and calcium levels, hypervitaminosis D, arteriosclerosis, and ectopic calcifications including vascular calcification [25]. KLOTHO interacts with the FGF23 receptor to take sodium-dependent type Ila phosphate transporters from the proximal renal tubular cell membrane, which causes phosphaturia. The effect of KLOTHO on urinary phosphate excretion may contribute to its inhibitory effect of ectopic calcification [24], [25].

This study shows that there is a significant relationship between the KLOTHO gene -395 polymorphisms and the incidence of carotid artery calcification with $p=0,015$, where patients with the GA and AA genotype are 4,071 times more likely to develop carotid artery calcification than patients with GG genotype ( $p=0,006)$. The KLOTHO gene G-395A 
polymorphisms, which is located in the region of the KLOTHO gene promoter, has never been reported to be related to the incidence of coronary artery disease in Europe. However, in Asian countries, for example, in Korea and Japan, the G-395A gene is considered as a risk factor for coronary artery disease [27].

In the research of Donate-Correa et al., in Spain, the KLOTHO gene -396 polymorphisms showed no significant results on the appearance of cardiovascular diseases such as vascular calcification. However, they found that KLOTHO mRNA expression was lower in subjects with coronary artery disease and the presence of A allele variant of KLOTHO gene G-395A polymorphism was associated with lower KLOTHO expression in vascular so the risk of causing vascular calcification and coronary artery disease [28]. But, studies of Rhee et al in Korea and Imamura et al in Japan showed that there was a statistically significant association between klotho gene G395A polymorphisms with the incidence of coronary artery disease and could be an independent risk factor for the incidence of coronary artery disease [29], [30].

Ko et al. have shown that the presence of A allele carriers from the KLOTHO -395 gene is associated with accelerated atherosclerosis manifested as coronary artery disease and hypertension [6]. This study shows that the presence of KLOTHO -395 gene A allele in a person can increase the risk of carotid artery calcification by 2,292 times compared to individuals with $\mathrm{G}$ allele ( $p=0,033$; $\mathrm{Cl} 95 \%=1,058$ 4,963). The KLOTHO gene G395A polymorphism has been reported to be related in influencing the promoter function of the gene, where G/A substitution has an effect on KLOTHO expression affecting the bone density (A allele forms fewer DNA-protein complexes compared to $G$ allele) [31]. Our finding was similar to those of Imamura et al., in which A allele carrier had a significantly higher incidence of coronary artery disease than controls [30].

Many clinical studies have tried to find an association between risk factors for coronary artery calcification or peripheral arterial calcification. Jensky et al., in California, showed that hypertension and diabetes had a significant risk of coronary atherosclerotic calcification characterized by calcium deposits in coronary arteries with $\mathrm{p}<0.01$ and $p<0.01$ [32]. In addition to KLOTHO gene -395 polymorphisms, diabetes and hypertension also have an association with risk factors for calcification in this study ( $p=0,022$ and $p=0,006$ ). Diabetes mellitus has a risk of increasing the incidence of coronary calcification, especially medial calcification, and the incidence of diabetic nephropathy increases that risk [33]. High blood sugar levels trigger the expression of osteoblast and osteocalcin transcription factors, thereby triggering calcification of vascular smooth muscle cells (VSMC) [34], [35]. Angiotensin renin system in hypertension plays an important role in the incidence of apoptosis, growth, and differentiation of VSMC, and therefore, these changes are likely to play a role in the occurrence of vascular calcification. [34], [36].

\section{Conclusion}

There was an association between the KLOTHO gene G395A polymorphism and carotid artery calcification in regular hemodialysis patients and the presence of KLOTHO -395 gene A allele can increase the risk of carotid artery calcification.

\section{References}

1. Mills KT, Xu Y, Zhang W, Bundy JD, Chen CS, Kelly T, et al A systematic analysis of worldwide population-based data on the global burden of chronic kidney disease in 2010. Kidney Int 2015;88(5):950-7. https://doi.org/10.1038/ki.2015.230 PMid:26221752

2. Hwang SJ, Tsai JC, Chen HC. Epidemiology, impact and preventive care of chronic kidney disease in Taiwan. Nephrology. 2010;15(Suppl 2):3-9. https://doi. org/10.1111/j.1440-1797.2010.01304.x

PMid:20586940

3. Jean G, Bresson E, Terrat JC, Vanel T, Hurot JM, Lorriaux C et al. Peripheral vascular calcification in long-haemodialysis patients: Associated factors and survival consequences. Nephrol Dial Transplant. 2008;24(3):948-55. https://doi.org/10.1093/ndt/ gfn571

PMid:18852190

4. Schoppet M, Shroff RC, Hofbauer LC, Shanahan CM. Exploring the biology of vascular calcification in chronic kidney disease: What's circulating? Kidney Int. 2008;73(4):384-90. https://doi. org/10.1038/sj.ki.5002696

PMid:18046319

5. Yamada S, Giachelli CM. Vascular calcification in CKD-MBD Roles for phosphate, FGF23. Bone. 2017;100:87-93. https://doi. org/10.1016/j.bone.2016.11.012

PMid:27847254

6. Ko GJ, Lee Ym, Lee EA, Lee JE, Bae SY, Park SW, et al. The association of klotho gene polymorphism with the mortality of patients on maintenance dialysis. Clin Nephrol. 2013;80(4):2639. https://doi.org/10.1016/j.cca.2009.06.011

PMid:23993164

7. Sripichai O, Fucharoen S. Genetic polymorphisms and implications for human diseases. J Med Assoc Thai. 2007;90(2):394-8.

PMid:17375650

8. Nazarian A, Hasankhani M, Aghajany-Nasab M, Monfared A. Association between klotho gene polymorphism and markers of bone metabolism in patients receiving maintenance hemodialysis in Iran. Iran J Kidney Dis. 2017;11(6):454-60. PMid:29190606

9. Shimoyama Y, Nishio K, Hamajima N, Niwa T. KLOTHO gene polymorphisms G-395a and C1818t are associated with lipid and glucose metabolism, bone mineral density and systolic 
blood pressure in Japanese healthy subjects. Clin Chim Acta. 2009;406(1-2):134-8.

PMid: 19539617

10. Bauer M, Caviezel S, Teynor A, Erbel R, Mahabadi AA, SchmidtTrucksäss A. Carotid intima-media thickness as a biomarker of subclinical atherosclerosis. Swiss Med Wkly. 2012;142:w13705. https://doi.org/10.4414/smw.2012.13705 PMid:23135891

11. Lebov JF, Valladares E, Peña R, Sanoff SL, Cisneros EC, Colindres RE, et al. A population-based study of prevalence and risk factors of chronic kidney disease in León, Nicaragua. Can J Kidney Health Dis. 2015;2:6. https://doi.org/10.1186/ s40697-015-0041-1

PMid:25926994

12. Carrero JJ, Hecking M, Chesnaye NC, Jager KJ. Sex and gender disparities in the epidemiology and outcomes of chronic kidney disease. Nat Rev Nephrol. 2018;14(3):151-64. https:// doi.org/10.1038/nrneph.2017.181

PMid:29355169

13. Doublier S, Lupia E, Catanuto P, Periera-Simon S, Xia X, Korach K, et al. Testosterone and $17 \beta$-estradiol have opposite effects on podocyte apoptosis that precedes glomerulosclerosis in female estrogen receptor knockout mice. Kidney Int. 2011;79(4):404-13. https://doi.org/10.1038/ki.2010.398 PMid:20962747

14. Maric C, Xu Q, Sandberg K, Hinojosa-Laborde C. Age-related renal disease in female Dahl salt-sensitive rats is attenuated with $17 \beta$-estradiol supplementation by modulating nitric oxide synthase expression. Gend Med. 2008;5(2):147-59. https://doi. org/10.1016/j.genm.2008.05.002

PMid:18573482

15. Goldberg I, Krause I. The role of gender in chronic kidney disease end-stage renal disease among. EMJ. 2016;1(2):58-64.

16. Indonesian Renal Registry. $10^{\text {th }}$ Report of Indonesian Renal Registry; 2017. Available from: https://www. indonesianrenalregistry.org/data/IRR\%202017\%20.pdf. [Last accessed on 2019 Apr 22].

17. Zhang L, Wang F, Wang L, Wang W, Liu B, Liu J, et al. Prevalence of chronic kidney disease in China: A crosssectional survey. Lancet. 2012;379(9818):815-22. https://doi. org/10.1016/s0140-6736(12)60033-6 PMid:22386035

18. Wang $\mathrm{XC}$, Liu $\mathrm{CH}$, Chen YJ, Wu Y, Yang LS, Liu HM, et al Clinical and pathological analysis of the kidney in patients with hypertensive nephropathy. Exp Ther Med. 2013;6:1243-6. PMid:24223652

19. Bernheim J, Benchetrit S. The potential roles of FGF23 and klotho in the prognosis of renal and cardiovascular diseases. Nephrol Dial Transplant. 2011;26:2433-8. https://doi. org/10.1093/ndt/gfr208

PMid:21543658

20. Ding HY, Ma HX. Significant roles of anti-aging protein KLOTHO and fibroblast growth factor 23 in cardiovascular disease. J Geriatr Cardiol. 2015;12:439-47.

PMid:26347327

21. Torres PU, Prie D, Molina-Bletry V, Beck L, Silve C, Friedlander G. KLOTHO: An Antiaging Protein Involved in Mineral and Vitamin D Metabolism. Kidney Int. 2007;71:730-7. https://doi.org/10.1038/sj.ki.5002163

22. Lu X, Hu MC. KLOTHO/FGF23 axis in chronic kidney disease and cardiovascular disease. Kidney Dis. 2017;3(1):15-23. https://doi.org/10.1159/000452880 PMid:28785560

23. Afanas'ev I. Reactive oxygen species and age-related genes p66Shc, sirtuin, FoxO3 and KLOTHO in senescence. Oxid
Med Cell Longev. 2010;3(2):77-85. https://doi.org/10.4161/ oxim.3.2.11050

PMid:20716932

24. Nitta K, Nagano N, Tsuchiya K. Fibroblast growth factor 23/ KLOTHO axis in chronic kidney disease. Nephron Clin Pract. 2014;128(1-2):1-10. https://doi.org/10.1159/000365787 PMid:25402964

25. Vervloet MG, Adema AY, Larsson TE, Massy ZA. The role of KLOTHO on vascular calcification and endothelial function in chronic kidney disease. Semin Nephrol. 2014;34(6):578-85. https://doi.org/10.1016/j.semnephrol.2014.09.003 PMid:25498377

26. Kim Y, Jeong SJ, Lee HS, Kim EJ, Song YR, Kim SG, et al. Polymorphism in the promoter region of the KLOTHO gene (G-395A) is associated with early dysfunction in vascular access in hemodialysis patients. Korean J Intern Med. 2008;23(4):2017. https://doi.org/10.3904/kjim.2008.23.4.201 PMid:19119257

27. Zhai C, Tang G, Qian G, Hu H, Gu A, Fang Y, et al. Polymorphism of KLOTHO G-395A and susceptibility of coronary artery disease in East-Asia population: A meta-analysis. Int J Clin Exp Med. 2015;8(2):1582-8.

PMid:25932086

28. Donate-correa J, Mart E, Mart R, Fuentes MM, Mora-Fernández $\mathrm{CC}$, Pérez-Delgado $\mathrm{N}$, et al. Influence of KLOTHO gene polymorphisms on vascular gene expression and its relationship to cardiovascular disease. J Cell Mol Med. 2016;20(1):128-33. https://doi.org/10.1111/jcmm.12710 PMid:26538295

29. Rhee E, Oh K, Lee W, Kim SY, Jung CH, Kim BJ, et al. The differential effects of age on the association of KLOTHO gene polymorphisms with coronary artery disease. J Metabol. 2006;55:1344-51. https://doi.org/10.1016/j. metabol.2006.05.020

PMid: 16979405

30. Imamura A, Okumura K, Ogawa $\mathrm{Y}$, Murakami R, Torigoe M, Numaguchi $Y$, et al. klotho gene polymorphism may be a genetic risk factor for atherosclerotic coronary artery disease but not for vasospastic angina in Japanese. Clin Chim Acta. 2006;371:6670. https://doi.org/10.1016/j.cca.2006.02.021 PMid:16579981

31. Jo S, Kim S, Choi YJ, et al. KLOTHO Gene Polymorphism Is Associated With Coronary Artery Stenosis but Not With Coronary Calcification in a Korean Population. Int Heart J. 2008;1:23-32. https://doi.org/10.1536/ihj.50.23

32. Jensky NE, Criqui MH, Wright MC, Wassel CL, Brody SA, Allison MA. Blood pressure and vascular calcification. Hypertension AHA. 2010;55:990-7. https://doi.org/10.1161/ hypertensionaha.109.147520

33. Arad Y, Goodman KJ, Roth M, Newstein D, Guerci AD Coronary calcification, coronary disease risk factors, C-reactive protein, and atherosclerotic cardiovascular disease events. $J$ Am Cool Cardiol. 2005;46:158-65. https://doi.org/10.1016/j. jacc.2005.02.088

34. Chen NX, Moe SM. Vascular calcification: Pathophysiology and risk factors. Curr Hypertens Rep. 2012;14(3):228-37. https://doi. org/10.1007/s11906-012-0265-8

35. Boström KI, Jumabay M, Matveyenko A, Nicholas SB, Yao Y Activation of vascular bone morphogenetic protein signaling in diabetes mellitus. Circ Res. 2011;108(4):446-57. https://doi. org/10.1161/circresaha.110.236596 PMid:21193740

36. Kalra SS, Shanahan CM. Vascular calcification and hypertension: Cause and effect. Ann Med. 2012;44(Suppl 1):S85-92.

PMid:22713153 